\title{
Methanotrophic Bacterial Biomass as Potential Mineral Feed Ingredients for Animals
}

\author{
Agnieszka Kuźniar ${ }^{1, *}$, Karolina Furtak ${ }^{2} \oplus$, Kinga Włodarczyk ${ }^{1}$, Zofia Stępniewska ${ }^{1}$ and \\ Agnieszka Wolińska ${ }^{1}$ (D) \\ 1 Department of Biochemistry and Environmental Chemistry, The John Paul II Catholic University of Lublin, \\ Konstantynów St. 1 I, 20-708 Lublin, Poland \\ 2 Department of Agriculture Microbiology, Institute of Soil Sciences and Plant Cultivation State Research \\ Institute, Czartoryskich St. 8, 24-100 Puławy, Poland \\ * Correspondence: agnieszka.kuzniar@kul.pl; Tel.: +48-81-454-5461
}

Received: 14 June 2019; Accepted: 23 July 2019; Published: 26 July 2019

\begin{abstract}
Microorganisms play an important role in animal nutrition, as they can be used as a source of food or feed. The aim of the study was to determine the nutritional elements and fatty acids contained in the biomass of methanotrophic bacteria. Four bacterial consortia composed of Methylocystis and Methylosinus originating from Sphagnum flexuosum (Sp1), S. magellanicum (Sp2), S. fallax II (Sp3), S. magellanicum IV (Sp4), and one composed of Methylocaldum, Methylosinus, and Methylocystis that originated from coalbed rock (Sk108) were studied. Nutritional elements were determined using the flame atomic absorption spectroscopy technique after a biomass mineralization stage, whereas the fatty acid content was analyzed with the GC technique. Additionally, the growth of biomass and dynamics of methane consumption were monitored. It was found that the methanotrophic biomass contained high concentrations of $\mathrm{K}, \mathrm{Mg}$, and Fe, i.e., approx. 9.6-19.1, 2.2-7.6, and 2.4-6.6 g kg-1, respectively. Consequently, the biomass can be viewed as an appropriate feed and/or feed additive for supplementation with macroelements and certain microelements. Moreover, all consortia demonstrated higher content of unsaturated acids than saturated ones. Thus, methanotrophic bacteria seem to be a good solution, in natural supplementation of animal diets.
\end{abstract}

Keywords: methanotrophic bacteria; nutritional values; feed ingredients; fatty acids

\section{Introduction}

Aerobic methanotrophs are a unique group of gram-negative bacteria capable of utilization of methane as a sole carbon and energy source [1]. Methanotrophs are present in a wide variety of environments and play an important role in the oxidation of methane in the natural world [2]. There are several reports in the literature database [1-5] that methanotrophic bacteria have been able to inhabit different environmental (sometimes extreme) niches like soils, deserts, landfills, tundra, wetlands, rice paddies, sediments, lakes, and marine environments [1], as well as the atmosphere [3] and coal [4] and salt mines [5].

For more than 30 years, bacteria oxidizing methane have attracted the attention of many researchers and aroused great interest in their industrial applications due to their unique microbiological and metabolic features [2]. Milestones in the study of obligate methanotrophs led to the discovery of their significant potential for applied microbiology, biotechnology, and biochemical engineering, including bioremediation of pollutants (e.g., halogenated hydrocarbons) via co-metabolism by the monooxygenase system (MMOs), biotransformation of diverse organic substrates (e.g., propylene to epoxypropane, production of chiral alcohols), assimilation of methane to mitigate greenhouse effects, and production of commercially relevant compounds, e.g., single cell protein, poly-hydroxybutyrate, 
astaxanthin [6]. One of the most recent discoveries is the potential of methanotrophic bacteria to compensate for food quantity or food quality limitations in Daphnia sp. [7,8]. The results confirm that methane-oxidizing bacteria, possessing sterols and sterol-like compounds, can finally lead to quantitative and qualitative upgrading of phytoplankton diets of Daphnia sp. What is more, a series of studies have demonstrated that the methanotrophic community may be a feed for protozoa and myxobacteria, as was confirmed that the composition of the methanotrophic community, in particular type I methanotrophs, changed dramatically during protozoan grazing [9-17]. The results obtained by Kiyashko et al. [10] suggest that Stictochironomus pictulus can directly feed upon methanotrophic bacteria, because its chironomid tissues contained large amounts of a fatty acid, 16:1 ( $n-8)$, which is specific to the type I methanotroph group (approximately $8 \%$ of total fatty acids).

Microorganisms have always been important in basic food processing techniques (e.g., fermentation) and can be used as a source of food or feed [11]. The first commercial product based on the microbial protein (MP) was the Pruteen ${ }^{\circledR}$ from Imperial Chemical Industries. Its production was based on the oxidation of methanol by Methylophilus methylotrophus [12]. However, vegetable (soybean) and animal (fishmeal) protein were analyzed for production but were not introduced into the market. The progress in science, especially biotechnology, allows the development of new microbial culture methods, fermentation conditions, and selection of microorganisms [13]. It has succeeded in achieving high production of MP from natural gas utilizing methanotrophic bacteria Methylococcus capsulatus, which resulted in the launch of a bacterial protein under the name FeedKind ${ }^{\circledR}[12,14]$. This product is comparable to traditional protein sources in terms of the amino acid profile and nutrient content. Methanotrophic protein has been used as a protein source for several animal species, including Atlantic salmon, rainbow trout, or pigs [14-17].

Biotechnology is now playing a major role in the pharmacotherapy of many diseases [18]. Biopharmaceuticals are naturally derived from living cells. As a result, their bio-structure is very complex and their mass is on average 100-1000 times higher than the mass of chemically synthesized pharmaceuticals [19]. Insulin, human growth hormone, blood coagulation factors, and monoclonal antibodies are such commonly used biopharmaceuticals [20]. Bacterial cultures also produce other substances that are important for medicine and cosmetology, e.g., ectoine [21]. The production of MP using methanotrophs yielded $25 \mathrm{~g} \mathrm{~L}^{-1}$ biomass. It contained $310 \mathrm{mg} \mathrm{kg}^{-1}$ of iron, $110 \mathrm{mg} \mathrm{kg}^{-1}$ of copper, $10-25 \mathrm{~g} \mathrm{~kg}^{-1}$ of phosphorus, $0.2 \%$ of magnesium, and $0.8 \%$ of potassium [22]. Methanotrophs also have the ability to collect and accumulate rare earth metals [23]. Currently, dietary supplements are produced in most cases by chemical synthesis. The natural solution seems to be an attempt to acquire these nutrients using biotechnological methods. Macronutrients and microelements thus obtained could be highly purified preparations (like other bacterial substances) available to the animal more readily than those derived from chemical syntheses. Bacterial biomass is a potential substitute for ingredients of animal and plant origin such as protein, microelements, and macroelements.

Consequently, the main goals of the study were to analyze the basic nutritional value contained in biomass of methanotrophic bacteria isolated from different environmental niches (endophytes of Sphagnum sp., coalbed rock) and to recognize the possibility to obtain fatty acids from methanotrophic bacteria. The important rationale behind undertaking these investigations is also the well-known fact that methanotrophic biomass is not pathogenic [24] and the presence of fatty acids is essential for cholesterol reduction $[25,26]$.

\section{Materials and Methods}

\subsection{Description of Samples}

Biomass originating from different bacterial consortia was studied (Table 1). The Sp1-Sp4 consortium was obtained and described previously by Stepniewska and Kuźniar [27]. It was found that this consortium includes the genera Methylocystis and Methylosinus [27]. The Sk108 consortium was isolated by Steppniewska et al. [28]. It is composed of three methanotroph strains belonging to genera: 
Methylocaldum, Methylosinus, and Methylocystis. DNA contents were determined spectrophotometrically (UV-1800, Shimadzu, Kioto, Japan) by measuring UV light absorbance of samples at wavelengths of $260 \mathrm{~nm}$ and $280 \mathrm{~nm}$. The measurement was triplicated.

Table 1. List of samples with DNA content $( \pm \mathrm{SD})$.

\begin{tabular}{ccc}
\hline Symbols & Explanations & DNA Concentration $\left(\mathbf{n g} \cdot \boldsymbol{\mu} \mathbf{L}^{-\mathbf{1}}\right)$ \\
\hline Sp1 & Consortium of methanotrophs from Sphagnum flexuosum & $26.47 \pm 0.04$ \\
Sp2 & Consortium of methanotrophs from Sphagnum magellanicum II & $32.22 \pm 0.05$ \\
Sp3 & Consortium of methanotrophs from Sphagnum fallax & $29.74 \pm 0.11$ \\
Sp4 & Consortium of methanotrophs from Sphagnum magellanicum IV & $39.85 \pm 0.16$ \\
Sk108 & Consortium of methanotrophs from coalbed rock & $43.55 \pm 0.12$ \\
\hline
\end{tabular}

\subsection{Culture Growth}

The bacterial consortia were grown in glass bottles (a capacity of $120 \mathrm{~cm}^{3}$ ) on liquid NMS medium. The medium, proposed in 1970 by Wittenbury [29], is most widely used for growth of methanotrophic bacteria. The NMS medium contained the following components (per $\mathrm{L}$ of distilled water): $\mathrm{KNO}_{3} 1.0 \mathrm{~g}$; $\mathrm{MgSO}_{4} \cdot 7 \mathrm{H}_{2} \mathrm{O} 1.0 \mathrm{~g} ; \mathrm{CaCl}_{2} \cdot \mathrm{H}_{2} \mathrm{O} 0.2 \mathrm{~g} ; 3.8 \%$ (w/v) Fe-EDTA solution $0.1 \mathrm{~mL} ; 0.1 \%(w / v) \mathrm{NaMo} \cdot 4 \mathrm{H}_{2} \mathrm{O}$ $0.5 \mathrm{~mL} ; \mathrm{KH}_{2} \mathrm{PO}_{4} 26 \mathrm{~g} ; \mathrm{Na}_{2} \mathrm{HPO}_{4} \cdot 7\left(\mathrm{H}_{2} \mathrm{O}\right) 62 \mathrm{~g}$. Additionally, $1 \mathrm{~mL}$ of a trace element solution was added (per $\mathrm{L}$ of water-distilled solution: $\mathrm{FeSO}_{4} \cdot 7 \mathrm{H}_{2} \mathrm{O} 500 \mathrm{mg} ; \mathrm{ZnSO}_{4} \cdot 7 \mathrm{H}_{2} \mathrm{O} 400 \mathrm{mg} ; \mathrm{MnCl}_{2} \cdot 7 \mathrm{H}_{2} \mathrm{O}$ $20 \mathrm{mg} ; \mathrm{CoCl}_{2} \cdot 6 \mathrm{H}_{2} \mathrm{O} 50 \mathrm{mg} ; \mathrm{NiCl}_{2} \cdot 6 \mathrm{H}_{2} \mathrm{O} 10 \mathrm{mg} ; \mathrm{H}_{3} \mathrm{BO}_{3}$ (boric acid) $15 \mathrm{mg}$; EDTA $250 \mathrm{mg}$ ). The $\mathrm{pH}$ was adjusted to 6.8 using $\mathrm{HCl}$. The glass bottles were incubated for seven days at $30^{\circ} \mathrm{C}$ with $180 \mathrm{rpm}$ shaking (Innova 42R, New Brunswick Scientific, Edison, NJ, USA). The growth of methanotrophs was stimulated by supplying $\mathrm{CH}_{4}(10 \% \mathrm{v} / \mathrm{v})$ for the cultivation. Bacterial multiplication yielded $400 \mathrm{~cm}^{3}$ of inoculum of each culture, which served to inoculate the NMS medium in the bioreactors. $4000 \mathrm{~cm}^{3}$ of the NMS liquid medium and $400 \mathrm{~cm}^{3}$ of the inoculum were placed in each bioreactor (separate for each sample). During the culture, a constant temperature of $30^{\circ} \mathrm{C}$ was maintained and air and methane $(10 \% v / v)$ were fed through a sterile filter $(0.25 \mathrm{~mm}$ diameter). The incubation lasted for 6 days. During this time, the concentration of bacterial cells was determined spectrophotometrically by measurement of absorbance at a wavelength of $600 \mathrm{~nm}$ (UV-1800, Shimadzu, Kioto, Japan). The gas phase in the bioreactor was analyzed by a gas chromatograph equipped with three detectors: flame ionization, thermal conductivity, and electron capture (GC 2010, Shimadzu, Kioto, Japan). Each measurement was performed in three replicates.

\subsection{Concentrations of the Nutrients}

The total concentrations of the respective elements were determined (in three replicates) using the flame atomic absorption spectroscopy (FAAS) technique (spectrometer Z-8200 Hitachi, Tokio, Japan) after mineralization of the material (Ethos One, Milestone, Italy). The results were converted to the concentration of each element in $1 \mathrm{~kg}$ of liquid bacterial biomass.

\subsection{Fatty Acid Analysis}

Extraction and preparation of fatty acids were performed with the method proposed by Guckert et al. [30] with own modifications. Briefly, an equivalent of $30 \mathrm{mg}$ dry weight of bacterial cells was used for extraction performed at room temperature in $142.5 \mathrm{~mL}$ chloroform/methanol/potassium phosphate buffer (1:2.5:0-8 by vol.; $100 \mathrm{mM}$, pH 7.4) for $3.5 \mathrm{~h}$. During this time, $37.5 \mathrm{~mL}$ of chloroform and the same volume of distilled water were added to separate the aqueous (upper) and organic (lower) phases overnight. The next steps were performed according to a procedure developed by Guckert et al. [30]. Samples for PLFA analysis were transesterified by mild alkaline methanolysis with methanolic $\mathrm{KOH}$ (methylated) to form PL-FAMEs. Then, the analysis of PL-FAMEs was carried out in the three replicates with the GC technique with an autosampler, split-splitless inlet, Rtx 2330 (Restek company, Bellefonte, PA, USA) column and flame ionization detector (Agilent Technologies, 
Wilmington, DE, USA). A split ratio of 30:1 was used with hydrogen carrier gas at a $1.2 \mathrm{~mL} \cdot \mathrm{min}^{-1}$ constant flow rate. The analysis was carried out in the following conditions: $80-220^{\circ} \mathrm{C}\left(10^{\circ} \mathrm{C} \cdot \mathrm{min}^{-1}\right)$, $220-230^{\circ} \mathrm{C}\left(2{ }^{\circ} \mathrm{C} \cdot \mathrm{min}^{-1}\right)$, and $230-260^{\circ} \mathrm{C}\left(30^{\circ} \mathrm{C} \cdot \mathrm{min}^{-1}\right)$. Fatty acids were identified with the use of standard solutions of fatty acids.

\subsection{Storage Options}

The storage ambient temperature was assessed by keeping the liquid culture at $22{ }^{\circ} \mathrm{C}$ for 1 week and incubating in optimal conditions for another one week.

Heat stress was tested by heating the cell suspensions at $80^{\circ} \mathrm{C}$ for $10 \mathrm{~min}$, cooling rapidly on ice, plating onto solid medium, and incubating under optimal conditions for 1 week.

Desiccation stress was assessed according to Whittenbury et al. [29] by air-drying suspensions of the consortium on glass slides and then inoculating into the medium after 1 week. Low stress was applied by cooling the cell suspensions at $4{ }^{\circ} \mathrm{C}$ for $48 \mathrm{~h}$ and then incubating in optimal conditions for 1 week.

Deep freezing was tested by freezing the cell suspensions of the consortium in liquid nitrogen. The culture was kept for 1 year and again incubated in optimal conditions for 1 week.

\subsection{Statistical Analysis}

Statistical analyses were performed using Statistica ver. 10.0 (StatSoft. Inc., Tulsa, OK, USA). Significant differences were calculated with the use of post hoc Tukey's HSD (honest significant difference) test at a significance level of $p<0.05$.

\section{Results}

\subsection{Biomass Growth and Dynamics of Methane Consumption}

The rate of methanotrophic biomass growth expressed as $\mathrm{OD}_{600}$ is presented in Figure 1. It was found that, after 6 days of incubation, sample Sk108 was characterized by the highest growth of biomass (2.42), whereas the growth of methanotroph biomass of the Sp1, Sp2, Sp3, and Sp4 combinations exhibited similar levels ranging from 1.01 to 1.21 .

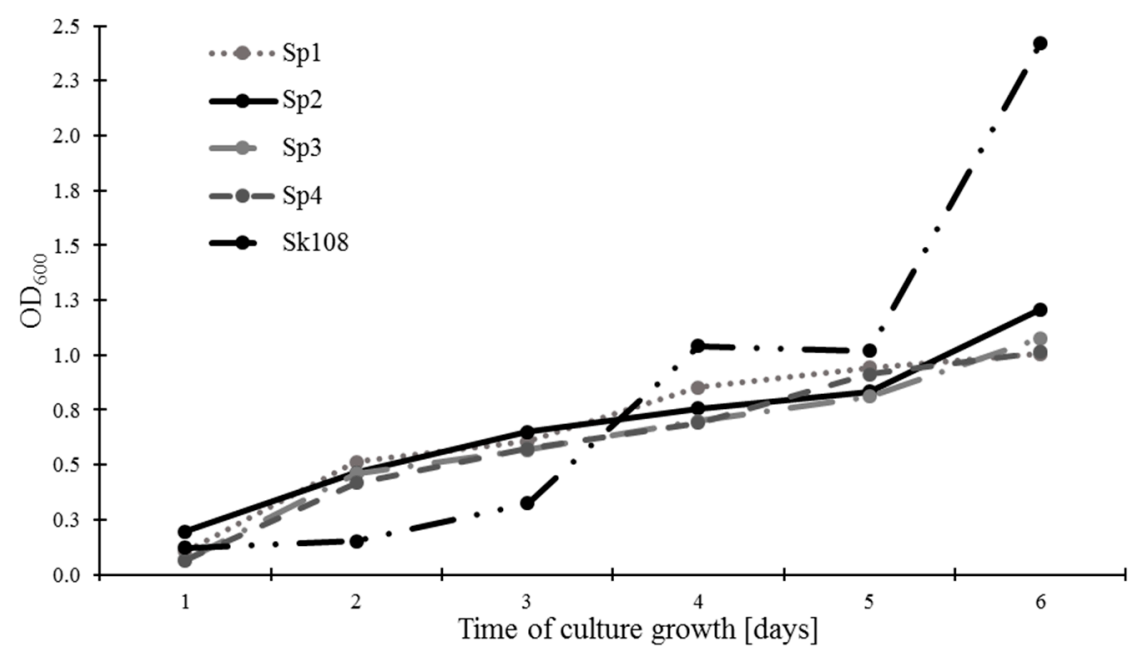

Figure 1. Studied biomass of methanotrophs during culture growth.

The dynamics of methane consumption by the methanotrophs during the incubation time are shown in Figure 2. 


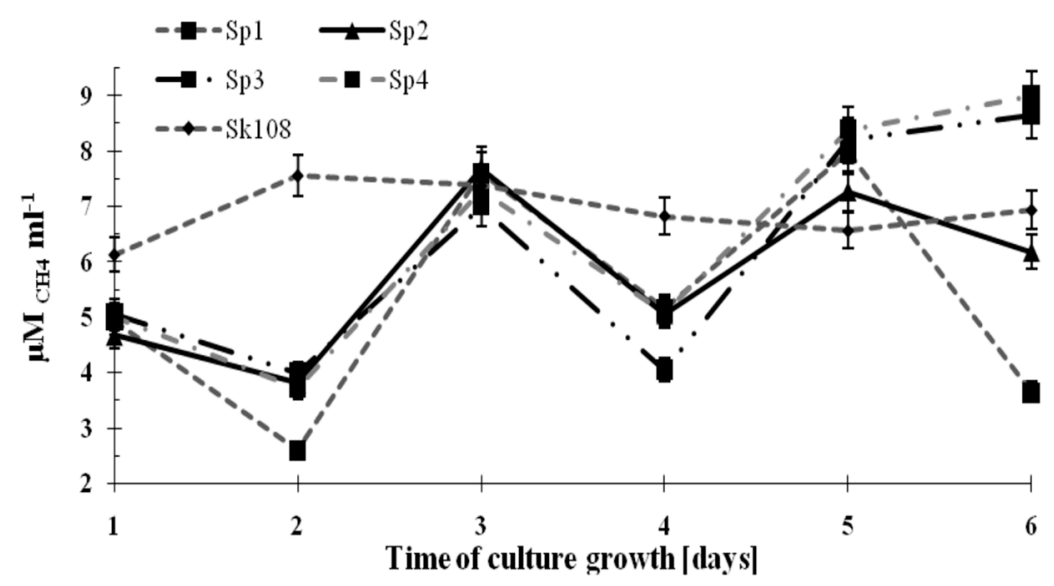

Figure 2. Dynamics of methane consumption by methanotrophs.

It was observed that methane consumption by samples Sp1, Sp2, Sp3, and Sp4 were similar and ranged from 4 to $8 \mu \mathrm{M} \mathrm{CH}_{4} \mathrm{~mL}^{-1}$. However, on the last incubation day, an increasing trend in $\mathrm{CH}_{4}$ consumption up to $8.5 \mu \mathrm{M} \mathrm{CH}_{4} \mathrm{~mL}^{-1}$ (Sp3) and $9 \mu \mathrm{M} \mathrm{CH}_{4} \mathrm{~mL}^{-1}$ (Sp4) was noted. Methane consumption in sample Sk108 over the 6 incubation days was at an almost constant level $(6.14-7.57 \mu \mathrm{M}$ $\left.\mathrm{CH}_{4} \mathrm{~mL}^{-1}\right)$.

The fluctuations in the values of methane consumption by the studied consortia are the consequence of supplementing only one source of carbon and energy $\left(\mathrm{CH}_{4}\right)$. Supplementation was applied every 2 days (Figure 2). These fluctuations did not affect the growth of the methanotrophic biomass.

\subsection{Fatty Acids in the Methanotrophic Biomass}

The results of the total fatty acid content of the biomass of the analyzed consortia are presented in Table 2.

Table 2. Contents of fatty acids in methanotrophic bacteria (nd-not detected).

\begin{tabular}{|c|c|c|c|c|c|c|c|c|c|c|}
\hline \multirow{2}{*}{$\begin{array}{l}\text { Type of } \\
\text { Biomass }\end{array}$} & \multicolumn{4}{|c|}{ Saturated Fatty Acids } & \multicolumn{5}{|c|}{ Unsaturated Fatty Acids } & \multirow[t]{2}{*}{$\begin{array}{l}\text { Unknown } \\
\text { Fatty Acids }\end{array}$} \\
\hline & C14:0 & C15:0 & C16:0 & C18:0 & C16:1w5 & 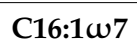 & C16:1w9 & C18:1w9 & C18:2w6 & \\
\hline Sp1 & 1.53 & nd & nd & 3.26 & nd & nd & 2.73 & 92.48 & nd & - \\
\hline Sp2 & nd & nd & 3.52 & 0.77 & nd & 1.34 & 0.50 & 92.39 & nd & 1.48 \\
\hline Sp3 & 0.90 & 0.15 & 12.31 & 1.68 & 1.36 & 19.75 & 22.91 & 38.04 & 0.93 & 1.97 \\
\hline Sp4 & nd & nd & 11.50 & 7.19 & 3.01 & 6.80 & 10.63 & 60.87 & nd & - \\
\hline Sk108 & 27.21 & 29.65 & 43.14 & 1.09 & nd & nd & nd & 67.15 & nd & - \\
\hline
\end{tabular}

The concentration of saturated acids oscillated from $4.29 \%$ to $32.85 \%$. The analysis of unsaturated fatty acids showed the presence of omega- $5(1.36 \%-3.01 \%)$, omega- $6(0.93 \%)$, omega-7 $(1.34 \%-19.75 \%)$, and omega-9 (0.5\%-92.48). The concentration of unsaturated fatty acids was similar in biomass Sp1, where it amounted to $95.21 \%$, and in Sp2 (94.23\%). In turn, lower levels were found in biomass Sp3 $(82.99 \%)$, Sp4 (81.56\%), and Sk108 (67\%). The presence of a small amount of unidentified acids was only reported in the consortia of Sp2 and Sp3 (1.48\% and 1.97\%, respectively). It was found that all consortia had higher contents of unsaturated acids than saturated acids.

\subsection{Macro- and Micronutrient Concentrations in the Methanotrophic Biomass}

The concentrations of macronutrients $(\mathrm{K}, \mathrm{Mg}, \mathrm{Ca}, \mathrm{Fe}$, and $\mathrm{Na})$ in the methanotrophic biomass are presented in Table 3. The highest content in the microbial biomass was recorded in the case of K (9.592-19.100 $\left.\mathrm{g} \cdot \mathrm{kg}^{-1}\right)$, followed by $\mathrm{Mg}\left(2.243-7.594 \mathrm{~g} \cdot \mathrm{kg}^{-1}\right)$, Fe $\left(2.436-6.594 \mathrm{~g} \cdot \mathrm{kg}^{-1}\right)$, and Ca $\left(2.008-3.274 \mathrm{~g} \cdot \mathrm{kg}^{-1}\right)$. 
Table 3. Contents of macronutrients in methanotrophic biomass.

\begin{tabular}{|c|c|c|c|c|c|}
\hline \multirow{2}{*}{ Biomass } & \multicolumn{5}{|c|}{ Macronutrients } \\
\hline & $\mathrm{K}\left[\mathrm{g} \cdot \mathrm{kg}^{-1}\right]$ & $\mathrm{Mg}\left[\mathrm{g} \cdot \mathrm{kg}^{-1}\right]$ & $\mathrm{Ca}\left[\mathrm{g} \cdot \mathrm{kg}^{-1}\right]$ & $\mathrm{Fe}\left[\mathrm{g} \cdot \mathrm{kg}^{-1}\right]$ & $\mathrm{Na}\left[\mathrm{g} \cdot \mathrm{kg}^{-1}\right]$ \\
\hline Sp1 & $10.031 \pm 0.01^{\mathrm{d}}$ & $6.086 \pm 0.006^{b}$ & $2.664 \pm 0.001^{c}$ & $3.286 \pm 0.001^{\mathrm{c}}$ & $1.910 \pm 0.0002^{a}$ \\
\hline Sp2 & $10.316 \pm 0.01^{\mathrm{c}}$ & $2.243 \pm 0.002 \mathrm{e}$ & $2.618 \pm 0.001^{c}$ & $2.436 \pm 0.001^{\mathrm{d}}$ & $1.562 \pm 0.0006^{b}$ \\
\hline Sp3 & $12.556 \pm 0.01^{b}$ & $3.274 \pm 0.003^{c}$ & $2.850 \pm 0.001^{b}$ & $4.408 \pm 0.0003^{b}$ & $1.331 \pm 0.001^{\mathrm{d}}$ \\
\hline Sp4 & $9.592 \pm 0.01^{\mathrm{e}}$ & $2.274 \pm 0.001^{\mathrm{d}}$ & $2.008 \pm 0.001^{d}$ & $2.480 \pm 0.001^{\mathrm{d}}$ & $1.373 \pm 0.0003^{\mathrm{c}, \mathrm{d}}$ \\
\hline Sk108 & $19.100 \pm 0.02^{a}$ & $7.594 \pm 0.002^{a}$ & $3.274 \pm 0.001^{a}$ & $6.594 \pm 0.002^{\mathrm{a}}$ & $1.422 \pm 0.001^{\mathrm{c}}$ \\
\hline
\end{tabular}

The presented values are the average of three replicates $(n=3) ; \pm$ standard deviation (SD); means marked with different letters $(\mathrm{a}-\mathrm{e})$ are significantly different at $p<0.05(n=3)$ as shown by Tukey's HSD test.

The lowest macronutrient content was found in respect to $\mathrm{Na}\left(1.331-1.910 \mathrm{~g} \cdot \mathrm{kg}^{-1}\right)$. Regardless of the element type, the highest potential for macronutrients accumulation was exhibited by methanotrophs consortium Sk108, followed by consortium Sp3. Considerable statistically significant differences were noted in the $\mathrm{K}$ and $\mathrm{Mg}$ content.

The concentrations of micronutrients $(\mathrm{Zn}, \mathrm{Cu}, \mathrm{Mn}$, and $\mathrm{Cr}$ were determined in the methanotrophic biomass (Table 4) analogically to the macronutrient contents.

Table 4. Contents of micronutrients in methanotrophic biomass.

\begin{tabular}{|c|c|c|c|c|}
\hline \multirow{2}{*}{ Biomass } & \multicolumn{4}{|c|}{ Micronutrients } \\
\hline & $\mathrm{Zn}\left[\mathrm{g} \cdot \mathrm{kg}^{-1}\right]$ & $\mathrm{Cu}\left[\mathrm{g} \cdot \mathrm{kg}^{-1}\right]$ & $\mathrm{Mn}\left[\mathrm{g} \cdot \mathrm{kg}^{-1}\right]$ & $\mathrm{Cr}\left[\mathrm{g} \cdot \mathrm{kg}^{-1}\right]$ \\
\hline Sp1 & $0.108 \pm 0.006^{c}$ & $0.476 \pm 0.021^{a}$ & $0.479 \pm 0.022^{b, c}$ & $<0.005^{c}$ \\
\hline Sp2 & $0.087 \pm 0.008^{d}$ & $0.175 \pm 0.033^{c}$ & $0.556 \pm 0.042^{b}$ & $0.009 \pm 0.035^{b}$ \\
\hline Sp3 & $0.142 \pm 0.004^{\mathrm{a}}$ & $0.279 \pm 0.019^{b}$ & $0.720 \pm 0.081^{\mathrm{a}}$ & $0.166 \pm 0.096^{\mathrm{a}}$ \\
\hline Sp4 & $0.096 \pm 0.002^{c, d}$ & $0.185 \pm 0.033^{c}$ & $0.395 \pm 0.001^{c}$ & $0.047 \pm 0.012^{\mathrm{a}, \mathrm{b}}$ \\
\hline Sk108 & $0.126 \pm 0.003^{b}$ & $0.416 \pm 0.029^{a}$ & $0.267 \pm 0.017^{\mathrm{d}}$ & $<0.005^{\mathrm{c}}$ \\
\hline
\end{tabular}

The values are the average of three replicates $(n=3) ; \pm$ standard deviation (SD); means marked with different letters $(\mathrm{a}-\mathrm{c})$ are significantly different at $p<0.05(n=3)$ as shown by Tukey's HSD test.

The micronutrient content was below $1 \mathrm{~g} \cdot \mathrm{kg}^{-1}$. Mn and $\mathrm{Cu}$ were present in the highest concentrations, i.e., $0.267-0.720 \mathrm{~g} \cdot \mathrm{kg}^{-1}$ and $0.175-0.476 \mathrm{~g} \cdot \mathrm{kg}^{-1}$, respectively. The content of $\mathrm{Zn}$ ranged from 0.087 to $0.142 \mathrm{~g} \cdot \mathrm{kg}^{-1}$, whilst $\mathrm{Cr}$ was found to be the least represented micronutrient $\left(0.009-0.166 \mathrm{~g} \cdot \mathrm{kg}^{-1}\right)$ Furthermore, no Cr was detected in two samples of bacterial biomass (Sp1 and Sk108) (Table 4). The differences in the content of the microelements were statistically significant.

\subsection{Dietary Requirements for Nutrients in Different Animals}

Table 5 presents daily (estimated) supplementation of macroelements originating from methanotrophic bacterial biomass in animals.

The addition of $1 \mathrm{~kg}$ of bacterial biomass to swine feed could ensure supplementation of $\mathrm{K}$ and Mg above the recommended daily intake (RDI; $191 \%-365 \%$ for $\mathrm{K}$ and $182 \%-617 \%$ for Mg). Addition of the analyzed biomass $(1 \mathrm{~kg})$ to swine feed could cover only $11 \%-17 \%$ and $51 \%-62 \%$ of their RDI Ca and Na demand, respectively.

In the case of dog feed, addition of $1 \mathrm{~kg}$ of the bacterial biomass originating from Sk108 could cover $27 \%$ and $6.4 \%$ of the RDI Mg and K demand, respectively.

In order to supplement $\mathrm{Ca}$ or $\mathrm{Na}$, the amount of added biomass should be increased, as $1 \mathrm{~kg}$ of the bacterial biomass does not cover even $2 \%$ of dog's daily needs for these minerals (Table 5). Nevertheless, addition of $1 \mathrm{~kg}$ of bacterial biomass originating from sample Sk108 to the feed can help supplement the amount of K (by $26 \%$ of the RDI) and $\mathrm{Mg}$ (by $45 \%$ of the RDI) in the cow's diet. This amount of bacterial biomass will also provide $14 \%$ and $5 \%$ of the daily Na and Ca demand, respectively (Table 5). 
Table 5. Estimated daily supplementation [\%] of macronutrients for selected animals with the use of methanotrophic bacterial biomass originating from different consortia. Each value is calculated for $1 \mathrm{~kg}$ of bacterial biomass (according to references [31-34]).

\begin{tabular}{|c|c|c|c|c|c|}
\hline Sample & $\mathbf{K}$ & $\mathrm{Mg}$ & $\mathrm{Ca}$ & $\mathbf{N a}$ & $\mathrm{Fe}$ \\
\hline \multicolumn{6}{|c|}{ Swine; 1 kg Bacterial Biomass } \\
\hline Sp1 & 191.80 & 494.80 & 14.14 & 62.01 & 2.67 \\
\hline Sp2 & 197.25 & 182.36 & 13.90 & 50.71 & 1.98 \\
\hline Sp3 & 240.08 & 266.18 & 15.13 & 43.21 & 3.58 \\
\hline Sp4 & 183.40 & 184.88 & 10.66 & 44.58 & 2.02 \\
\hline Sk108 & 365.20 & 617.40 & 17.38 & 46.17 & 5.36 \\
\hline \multicolumn{6}{|c|}{ Dog; 1 kg Bacterial Biomass } \\
\hline Sp1 & 3.34 & 22.21 & 0.39 & 1.91 & 53.87 \\
\hline Sp2 & 3.44 & 8.19 & 0.39 & 1.56 & 39.93 \\
\hline Sp3 & 4.19 & 11.95 & 0.42 & 1.33 & 72.26 \\
\hline Sp4 & 3.20 & 8.30 & 0.30 & 1.37 & 40.66 \\
\hline Sk108 & 6.37 & 27.72 & 0.48 & 1.42 & 108.10 \\
\hline \multicolumn{6}{|c|}{ Dairy Cattle; 1 kg Bacterial Biomass } \\
\hline Sp1 & 13.78 & 36.23 & 4.23 & 13.64 & 1.81 \\
\hline Sp2 & 14.17 & 13.35 & 4.16 & 11.16 & 1.34 \\
\hline Sp3 & 17.25 & 19.49 & 4.52 & 9.51 & 2.42 \\
\hline Sp4 & 13.18 & 13.54 & 3.19 & 9.81 & 1.36 \\
\hline Sk108 & 26.24 & 45.20 & 5.20 & 10.16 & 3.62 \\
\hline \multicolumn{6}{|c|}{ Broiler Chicken; 1 Kg Bacterial Biomass } \\
\hline Sp1 & 83.59 & 1014.33 & 8.33 & 39.79 & 4.11 \\
\hline Sp2 & 85.97 & 373.83 & 8.18 & 32.54 & 3.05 \\
\hline Sp3 & 104.63 & 545.67 & 8.91 & 27.73 & 5.51 \\
\hline Sp4 & 79.93 & 379.00 & 6.28 & 28.60 & 3.10 \\
\hline Sk108 & 159.17 & 1265.67 & 10.23 & 29.63 & 8.24 \\
\hline
\end{tabular}

The amount of $\mathrm{Mg}$ contained in $1 \mathrm{~kg}$ of the bacterial biomass is a multiple of the daily requirement for this element in broiler chickens. This amount of biomass contains up to 159\% (Sk108) of the broiler chicken's daily potassium demand and up to $40 \%$ (Sp1) of the daily Na dose.

The macroelements content in $1 \mathrm{~kg}$ of the consortium Sk108 bacterial biomass could provide 108\% of the daily Fe dose for dogs, $8.24 \%$ for broiler chickens, 5.36\% for swine, and 3.62\% for cows. The largest percentage of supplementation of all macroelements could be provided by the addition of the biomass of consortium Sk108 bacteria (Table 5).

The highest percentage of copper RDI could be provided by addition of $1 \mathrm{~g}$ of the biomass of the studied consortium for dogs (from $23.12 \%$ by Sp2 to $62.68 \%$ by Sp1) (Table 6 ).

An addition of $1 \mathrm{~g}$ of the bacterial biomass from the $\mathrm{Sp} 3$ consortium to feed could provide from $0.29 \%$ of the daily Mn dose for cows to $189.5 \%$ for dogs. The $\mathrm{Zn}$ content in the bacterial biomass $(1 \mathrm{~g})$ would represent from $0.03 \%$ (Sp2 and Sp4) of daily requirement for this element for swine to $2.08 \%$ (Sp3) for dogs. In the case of Mn, the highest percentage of daily consumption could be provided by addition of $1 \mathrm{~g}$ of the biomass of the studied consortium for dogs: $70.41 \%$ by Sk108, $104.04 \%$ by Sp4, $126.12 \%$ by Sp1, $146.41 \%$ by Sp2 and $189.55 \%$ by Sp 3 . 
Table 6. Estimated daily supplementation [\%] of microelements for selected animals with the use of methanotrophic bacterial biomass originating from different consortia. Each value is calculated for $1 \mathrm{~g}$ of bacterial biomass (according to references [31-34]).

\begin{tabular}{cccc}
\hline Sample & Zn & Cu & Mn \\
\hline \multicolumn{4}{c}{ Swine; $\mathbf{1}$ g Bacterial Biomass } \\
\hline Sp1 & 0.07 & 5.16 & 7.79 \\
Sp2 & 0.06 & 1.90 & 9.05 \\
Sp3 & 0.09 & 3.03 & 11.71 \\
Sp4 & 0.06 & 2.01 & 6.43 \\
Sk108 & 0.08 & 4.51 & 4.35 \\
\hline \multicolumn{4}{c}{ Dog; $\mathbf{1}$ g Bacterial Biomass } \\
\hline Sp1 & 1.58 & 62.68 & 126.12 \\
Sp2 & 1.28 & 23.12 & 146.41 \\
Sp3 & 2.08 & 36.75 & 189.55 \\
Sp4 & 1.41 & 24.37 & 104.04 \\
Sk108 & 1.85 & 54.76 & 70.41 \\
\hline Dairy cattle; $\mathbf{1}$ g Bacterial Biomass \\
\hline Sp1 & 0.04 & 0.26 & 0.19 \\
Sp2 & 0.03 & 0.10 & 0.22 \\
Sp3 & 0.05 & 0.15 & 0.29 \\
Sp4 & 0.03 & 0.10 & 0.16 \\
Sk108 & 0.04 & 0.23 & 0.11 \\
\hline Broiler Chicken; $\mathbf{~ g ~}$ & Bacterial Biomass \\
\hline Sp1 & 0.27 & 5.95 & 0.80 \\
Sp2 & 0.22 & 2.20 & 0.93 \\
Sp3 & 0.36 & 3.49 & 1.20 \\
Sp4 & 0.24 & 2.32 & 0.66 \\
Sk108 & 0.32 & 5.20 & 0.45 \\
\hline \multicolumn{4}{r}{}
\end{tabular}

\subsection{Storage Options for Methanotrophic Biomass}

The methanotrophic activity in optimal conditions of culture $\left(30^{\circ} \mathrm{C}\right.$, aerobic condition) was in the range of 1.364-2.123 $\mu \mathrm{M} \mathrm{CH}_{4} \mathrm{~mL}^{-1} \mathrm{~d}^{-1}$ (Table 7).

The methane oxidation rate at ambient temperature was comparable to the $\mathrm{CH}_{4}$ consumption in the studied consortium grown in optimal culture conditions, i.e., from 1.429 to $2.127 \mu \mathrm{M} \mathrm{CH}_{4} \mathrm{~mL}^{-1} \mathrm{~d}^{-1}$. In turn, the methanotrophic activity of the consortium significantly decreased from 0.075 to 0.147 $\mu \mathrm{M} \mathrm{CH}_{4} \mathrm{~mL}^{-1} \mathrm{~d}^{-1}$ at lower temperature $\left(4^{\circ} \mathrm{C}\right)$. During the thermal treatment $\left(80^{\circ} \mathrm{C}\right.$ for $\left.10 \mathrm{~min}\right)$, the highest methane consumption was observed in consortia Sp1 and Sp4, i.e., 2.173 and $2.013 \mu \mathrm{M} \mathrm{CH}_{4}$ $\mathrm{mL}^{-1} \mathrm{~d}^{-1}$, respectively.

After direct deep freezing, the methanotrophic activity of the studied consortium was lowered. The $\mathrm{CH}_{4}$ consumption value ranged from 0.025 to $0.819 \mu \mathrm{M} \mathrm{CH}_{4} \mathrm{~mL}^{-1} \mathrm{~d}^{-1}$. The viability of the studied consortium exhibited a varied level.

The experimental conditions, i.e., ambient and low temperature caused slight changes in culture viability, which ranged from 74.125 to $89.008 \mu \mathrm{M} \mathrm{CH}_{4} \mathrm{~mL}^{-1} \mathrm{~d}^{-1}$. During storage in the drying conditions, the relative percentage of viable bacterial consortia Sk108, Sp3, and Sp4 decreased dramatically, compared to optimal conditions of consortium growth. Survival during this storage type in the Sp1 and Sp2 biomass was at a level of 50\%-55\%. The highest cell viability reduction was noted during the thermal treatment. Survival during this storage had values from $5.231 \%$ to $33.586 \%$. The LIVE/DEAD staining test demonstrated $14.957 \%-23.595 \%$ viability of the cell consortium after deep freezing. 
Table 7. Methanotrophic activity and viability of the analyzed biomass in the storage options.

\begin{tabular}{|c|c|c|c|c|c|c|c|c|c|c|}
\hline \multirow{2}{*}{ Storage Options } & \multicolumn{5}{|c|}{ Methanotrophic Activity $\left[\mu \mathrm{MCH} \mathrm{CH}_{4} \mathrm{~mL}^{-1} \mathrm{~d}^{-1}\right.$ ] } & \multicolumn{5}{|c|}{ Viability [\%] } \\
\hline & Sp1 & Sp2 & Sp3 & Sp4 & Sk108 & Sp1 & Sp2 & Sp3 & Sp4 & Sk108 \\
\hline Ambient temperature & $1841^{\mathrm{c}, \mathrm{V}}$ & $2127^{a, u}$ & $1462^{\mathrm{d}, \mathrm{v}}$ & $1947^{b, c, u}$ & $1429 \mathrm{~d}, \mathrm{u}$ & $82,145^{\mathrm{c}, \mathrm{v}}$ & $75,250 \mathrm{~d}, \mathrm{v}$ & $89,008^{a, v}$ & $85,131^{b, v}$ & $86,705^{a, b, v}$ \\
\hline Low temperature & $1146^{\mathrm{b}, \mathrm{w}}$ & $1546^{\mathrm{a}, \mathrm{v}}$ & $0.954^{\mathrm{c}, \mathrm{W}}$ & $0.871^{\mathrm{c}, \mathrm{v}}$ & $0.431^{\mathrm{d}, \mathrm{w}}$ & $82,462^{a, b, v}$ & $74,125^{\mathrm{d}, \mathrm{v}}$ & $82,014^{\mathrm{b}, \mathrm{c}, \mathrm{w}}$ & $80,146^{\mathrm{c}, \mathrm{w}}$ & $84,264^{\mathrm{a}, \mathrm{w}}$ \\
\hline Heat temperature & $2173^{a, u}$ & $0.488^{\mathrm{d}, \mathrm{w}}$ & $0.974^{\mathrm{b}, \mathrm{w}}$ & $2013^{a, u}$ & $0.714^{\mathrm{c}, \mathrm{v}}$ & 5,231 e,y & $11,565^{b, y}$ & $6894^{\mathrm{d}, \mathrm{z}}$ & $33,586^{a, x}$ & $8,542 \mathrm{c}, \mathrm{y}$ \\
\hline Deep freezing & $0.819^{a, x}$ & $0.072^{b, c, x}$ & $0.034^{b, c, x}$ & $0.025^{c, x}$ & $0.098^{b, x}$ & $12,159^{e, x}$ & $14,957^{\mathrm{d}, \mathrm{x}}$ & $23,595^{b, x}$ & $24,959^{a, y}$ & $17,507^{c, x}$ \\
\hline Optimal condition of culture & $1954^{\mathrm{a}, \mathrm{b}, \mathrm{uv}}$ & $2123^{a, u}$ & $1756^{\mathrm{b}, \mathrm{u}}$ & $1994^{a, b, u}$ & $1364^{\mathrm{c}, \mathrm{u}}$ & $96,354^{b, c, u}$ & $97,365^{a, b, u}$ & $95,654^{c, u}$ & $96,468^{b, c, u}$ & $98,654^{a, u}$ \\
\hline
\end{tabular}

Different letters indicate significant differences as shown by Tukey's HSD test at $p<0.05$. Values with different letters "a-e" (in the rows) indicate significant difference for different biomass

at the same storage options, and " $\mathrm{u}-\mathrm{z}$ " (in the columns) indicate significant difference for the same biomass in different storage options; both at $p \leq 0.05$ in Tukey's HSD test. 


\section{Discussion}

Given the literature data regarding the metabolism of methanotrophs, it can be concluded that their biomass contains large quantities of $\mathrm{Ca}$ [35], $\mathrm{Cu}$ [36], and $\mathrm{P}$ [17,37]. These elements are also cofactors of the major enzymes involved in the biological oxidation of methane: methane monooxygenase (pMMO and sMMO), methanol dehydrogenase, and formate dehydrogenase. The results of our research demonstrated high contents of $\mathrm{K}, \mathrm{Mg}$, and Fe in the methanotrophic bacterial biomass (Table 3), i.e., approx. 9.6-19.1, 2.2-7.6, and 2.4-6.6 g kg-1, respectively. The Ca and Na contents were lower, i.e., in the range of 2-3.3 and 1.3-1.9 $\mathrm{g} \mathrm{kg}^{-1}$, respectively (Table 3). In turn, the Cu concentration of the biomass was much lower than assumed $\left(0.1-0.4 \mathrm{~g} \mathrm{~kg}^{-1}\right)$. However, our results suggest that the biomass of methanotrophic bacteria can be an appropriate feed and feed additive for supplementation with macroelements $(\mathrm{K}, \mathrm{Mg}, \mathrm{Ca}, \mathrm{Na}, \mathrm{Fe})$ and certain microelements $(\mathrm{Cu}, \mathrm{Mn})$. In addition, as shown by other data, the biomass of methanotrophic bacteria is also rich in vitamins B (niacin, riboflavin) [14], which is an additional advantage from the dietary point of view. The methanotrophic bacterial biomass can be added to feed in the form of freeze-dried feeding stuffs.

Some methanotrophic bacteria e.g., Methylomonas methanica and Methylococcus capsulatus are also used for the production of single cell protein added to animal feeds [38,39]. In the production of single cell proteins (SCP) using M. capsulatus, biomass containing $310 \mathrm{mg} \mathrm{kg}^{-1}$ of Fe and $110 \mathrm{mg} \mathrm{kg}^{-1} \mathrm{of} \mathrm{Cu}$ was obtained [22]. However, it should be underlined that these bacteria (M. capsulatus) were grown in an industrial culture of mixed M. capsulatus Bath with Bacillus brevis DB4, Bacillus firmuj DB5, and Alcaligenes acidovorans DB3; therefore, it cannot be claimed that the content of $\mathrm{Cu}$ and Fe originated only from the biomass of $M$. capsulatus. The production of single cell proteins using methanotrophs ensures an amino acid composition comparable to that of fishmeal and soybean meal [14,40]. In 2005, the EU approved protein derived from bacterial biomass growing on natural gas for use in pig, calf, and salmon diets [41]. The process of SCP production based on M. capsulatus was designed to fine-tune proteins for salmon, chickens, and pigs. However, this proved to be uneconomic because of the high price of natural gas [42,43]. Therefore, SCP production based on methane from natural sources (e.g., sediments, landfills) is a promising research trend. Aas et al. [15] have shown that the addition of biomass of methanotrophic bacteria (36\%) to the salmon diet increased the retention of $\mathrm{N}$ in the fish body (resulting in higher retention of $\mathrm{N}$ and energy). An increase in salmon body weight was observed as well $[14,44]$.

Yet, it is important that methanotrophic bacterial biomass cannot be used in human nutrition due to the excessive nucleic acid content. An option is to partially remove and decompose nucleic acids from biomass [11]. Nevertheless, it has been found that methanotrophic microorganisms can be food for protozoa and mucous bacteria [9]. In the case of Daphnia, a community of methanotrophs leads to quantitative and qualitative improvement in the diet [7,8]. A similar finding has also been demonstrated in Stictochironomus pictulus, which can directly feed on methanotrophic bacteria [10].

Unsaturated acids from the omega-3 (e.g., $\alpha$-linolenic acid) and omega-6 (e.g., linoleic acid and arachidonic acid) groups were shown to exert health effects on animals and should therefore be delivered to the body along with food. The presence of these acids in the diet reduces blood cholesterol levels, increases immunity, and is essential for normal brain function. Our analysis of unsaturated fatty acids proved that omega-5, omega-6, omega-7, and omega-9 acids are present in the consortia of methanotrophic bacteria. The presence of high levels of unsaturated fatty acids in the Sp1 and Sp2 consortia indicates that they can potentially be used to obtain these acids in the biotechnology industry. Unsaturated acids produced by bacteria could be used in animal feed and medicinal products. From this point of view, the biomass addition to animal feed and supplementation of unsaturated acids are more important for animal health than saturated acids. The appropriate concentration of unsaturated fatty acids has an impact on the quality of meat, milk, or eggs obtained from farmed animals. The supply of these acids with food is also directly reflected in the fatty acid profile that will be present in animal organisms [45]. Bacterial fatty acids could therefore be used in pharmaceuticals, nutraceuticals, and food. Furthermore, methanotrophs are particularly effective in the production of 
lipids, as their PLFAs represent more than $30 \%$ by weight [46]. A patent for the production of fatty acids from methanotrophs to reduce cholesterol [47] has already been developed.

Furthermore, several studies have shown that the use of methanotrophic biomass can improve meat quality in monogastric farm animals (swine, dairy cattle, broiler chicken) [48-50]. No mortality or negative effects of methane prophyroid biomass on clinical health of tested animals or changes in food ducts have been observed. Methanotrophic biomass is well tolerated by all tested animal species. Importantly, these bacteria are not pathogenic [37,44,48]. In addition, such protein does not contain toxins and GMOs, as it is a completely natural product and can be used as a protein feed ingredient $[38,51]$.

The nucleic acid concentration is an important feature of biomass that can be used as a diet, as uric acid is the product of purine metabolism, whose high concentration contributes to development and intensification of the symptoms of gout. The maximum permitted daily dose of nucleic acids for an adult human is $4 \mathrm{~g}$ [52]. That is why it is so important to determine the concentration of nucleic acids in the cultured biomass. In our study, the DNA content in methanotrophic biomass (Table 2) was significantly lower than the maximum permitted dose, i.e., it ranged from 26.47 to $43.55 \mathrm{ng} / \mu \mathrm{L}$. The calculated DNA concentration was in agreement with values presented by Lau et al. [53], who also measured the DNA content in Sphagnum and samples taken from peat soils. This additionally confirms the safety of methanotrophic biomass for application as a feed ingredient for animals.

Last but not the least, an important highlight is the fact that methanotrophic bacteria belong to the mesophilic group of microorganisms, which means that the temperature optimum for their growth is between 20 and $37^{\circ} \mathrm{C}$ [54], whereas the minimum and maximum are $10-30^{\circ} \mathrm{C}$ and $35-50{ }^{\circ} \mathrm{C}$, respectively [55]. Temperature is an extremely important aspect of biomass storage conditions regulating methanotrophic activity and mineral content. Our study evidenced that the optimal temperature for biomass storage should oscillate between 10 and $30{ }^{\circ} \mathrm{C}$, which means that an easy way of providing methanotrophic biomass storage involves providing room temperature. Nevertheless, sterile conditions must be maintained, because, a majority of microorganisms found in nature are unfortunately included in the group of mesophile. Consequently, there are both saprophytic and pathogenic organisms in this group [56].

Another unquestionable benefit of using methanotrophic bacteria as an additive to feed is the possibility of using mineral growth medium [5] guaranteeing the absence of other microorganisms-e.g., from the Enterobacteriaceae family, which may potentially be harmful in nutrition. Additionally, through the application of methanotrophic biomass to feed, it is possible to avoid any GMO modifications and use of any genetic engineering to increase the synthesis of the vitamin due to the high plasticity of methanotroph metabolism. What is more, the product proposed by us comprises natural, non-toxic strains, thus eliminating a conflict with society resulting from the lack of acceptance of technologies based on modified organisms.

\section{Conclusions}

In this paper, we have presented the possibility of use of methanotrophic bacterial biomass as potential mineral feed ingredients dedicated to different animals. It was shown that all biomass obtained from the studied consortium had higher contents of unsaturated acids than saturated acids. Moreover, the analyzed biomass displayed high potential for accumulation of macronutrients and micronutrients. We concluded that the conditions of cell consortium storage are very important. The low temperature $\left(4^{\circ} \mathrm{C}\right)$ was proved to be the most suitable for biomass storage, while ambient temperature contributed to high bacterial cell survival. Currently, modern biotechnology is looking for microorganisms with unique metabolic characteristics (especially having health-enhancing properties) that are easy to grow and use a cheap source of carbon and energy. In this context, methanotrophic bacteria seem to be a pioneering solution and a new perspective, e.g., in supplementing animal diets, or as a new source of substances with a beneficial effect on the development and growth of animals. 
Author Contributions: Conceptualization, A.K. and A.W.; methodology, A.K. and A.W.; investigation, K.F., A.K., K.W. and A.W.; writing-original draft preparation, A.K., K.F. and A.W.; writing-review and editing, A.K., K.F., A.W. and Z.S.; visualization, A.K. and K.W.; supervision, A.W. and Z.S.

Funding: This work was partly supported by the National Science Centre grant in Poland (No 2011/01/N/ NZ9/06811).

Acknowledgments: Authors are grateful to students: Małgorzata Woźniak and Agnieszka Szostak for their help in experiment performing.

Conflicts of Interest: The authors declare no conflict of interest.

\section{References}

1. Hanson, R.S.; Hanson, T.E. Methanotrophic bacteria. Microbiol. Rev. 1996, 60, 439-471. [PubMed]

2. Jiang, H.; Chen, Y.; Jiang, P.; Zhang, C.; Smith, T.; Murrell, J.C.; Xing, X.H. Methanotrophs: Multifunctional bacteria with promising applications in environmental bioengineering. Biochem. Eng. J. 2010, 49, 277-288. [CrossRef]

3. Šantl-Temkiv, T.; Finster, K.; Munk Hansen, B.; Pašić, L.; Gosewinkel Karlson, U. Viable methanotrophic bacteria enriched from air and rain can oxidize methane at cloud-like conditions. Aerobiologia 2013, 29, 373-384. [CrossRef]

4. Stępniewska, Z;; Pytlak, A. Methanotrophic activity of coalbed rocks from "Bogdanka" coal mine (south-east Poland). Arch. Environ. Prot. 2008, 34, 183-191.

5. Stępniewska, Z.; Goraj, W.; Wolińska, A.; Szafranek-Nakonieczna, A.; Banach, A.; Górski, A. Methanotrophic activity of rocks surrounding badenian salts in the Wieliczka salt mine. Carpathian J. Earth Environ. Sci. 2017, 13, 107-119. [CrossRef]

6. Trotsenko, Y.A.; Doronna, N.; Khmelenna, V.N. Biotechnological potential of aerobic methylotrophic bacteria: A review of current state and future prospect. Appl. Biochem. Microb. 2006, 41, 433-441. [CrossRef]

7. Deines, P.; Fink, P. The potential of methanotrophic bacteria to compensate for food quantity of food quality limitations in Daphnia. Aquat. Microb. Ecol. 2011, 65, 197-206. [CrossRef]

8. Martin-Creuzburg, D.; Beck, B.; Freese, H.M. Food quality of heterotrophic bacteria for Daphnia magna: Evidence for a limitation by sterols. FEMS Microbiol. Ecol. 2011, 76, 592-601. [CrossRef]

9. Murase, J.; Frenzel, P. A methane-driven microbial food web in a rice field soil. In Proceedings of the World Congress of Soil Science, Soil Solutions for a Changing World, Brisbane, Australia, 1-6 August 2010; pp. 1-4.

10. Kiyashko, S.I.; Imbs, A.B.; Narita, T.; Svetashev, V.I.; Wada, E. Fatty acid composition of aquatic insect larvae Stictochironomus pictulus (Diptera: Chironomidae): Evidence of feeding upon methanotrophic bacteria. Comp. Biochem. Physiol. 2004, 139, 705-711. [CrossRef]

11. Ravindra, A.P. Value-added food: Single cell protein. Biotechnol. Adv. 2000, 18, 459-479. [CrossRef]

12. Westlake, R. Large-scale continuous production of single cell protein. Chem. Ing. Tech. 1986, 58, 934-937. [CrossRef]

13. Kupferschmidt, K. Why insects could be the idea animal feed. Science 2015. [CrossRef]

14. Øverland, M.; Tauson, A.H.; Shearer, K.; Skrede, A. Evaluation of methane-utilising bacteria products as feed ingredients for monogastric animals. Arch. Anim. Nutr. 2010, 64, 171-189. [CrossRef] [PubMed]

15. Aas, T.S.; Grisdale-Helland, B.; Terjesen, B.F.; Helland, S.J. Improved growth and nutrient utilisation in Atlantic salmon (Salmo salar) fed diets containing a bacterial protein meal. Aquaculture 2006, 259, 365-376. [CrossRef]

16. Romarheim, O.H.; Øverland, M.; Mydland, L.T.; Skrede, A.; Landsverk, T. Bacteria grown on natural gas prevent soybean meal-induced enteritis in Atlantic salmon. J. Nutr. 2011, 141, 124-130. [CrossRef] [PubMed]

17. Strong, P.J.; Xie, S.; Clarke, W.P. Methane as a resource: Can the methanotrophs add value? Environ. Sci. Technol. 2015, 49, 4001-4018. [CrossRef] [PubMed]

18. Nowicki, M.; Zimmer-Nowicka, J. Original biotechnology medicines and biosimilars-What one should know to provide safety of treatment? Onk. Prakt. Klin. Med. 2007, 3, 120-127. (In Polish)

19. Roger, S.D. Biosimilars: How similar or dissimilar they are? Nephrology. 2006, 11, 341-346. [CrossRef]

20. Schmidt, C.A.; Ramos, A.S.; Da Silva, J.E.P.; Fronza, M.; Dalmora, S.L. Activity evaluation and characterization of recombinant human erythroprotein in pharmaceutical products. Arq. Bras. Endocrinol. Metabol. 2003, 47, 183-189. [CrossRef] 
21. Stępniewska, Z.; Kuźniar, A.; Pytlak, A.; Cieplielski, J. Ectoine-An antistress molecule of the future. Kosmos 2014, 63, 25-35.

22. Trotsenko, Y.A.; Stepniewska, Z. Biology and Biotechnology of Aerobic Methylotrophs; Wydawnictwo KUL: Lublin, Poland, 2012; pp. 1-194.

23. Pol, A.; Barends, T.; Dietl, A.; Khadem, A.F.; Eygensteyn, J.; Jetten, M.S.M.; Op Den Camp, H.J. Rare earth metals are essential for methanotrophic life in volcanic mudpots. Environ. Microbiol. 2015, 16, 255-264. [CrossRef] [PubMed]

24. Apel, W.A.; Dugan, P.R.; Wiebe, M.R. Use of Methanotrophic Bacteria in Gas Chase Bioreactors to Abace Methane in Coal Mine Atmosphere; The Idaho National Engineering Laboratory: Fowles, ID, USA, 1991; pp. 943-950.

25. Müller, H.; Skrede, A.; Kleppe, G. Lipids from Methanotrophic Bacteria for Cholesterol Reduction. U.S. Patent No. US 2007/0060648 A1, 15 March 2007.

26. Koffas, M.; Odom, J.M.; Schenzle, A. Production of Feed Using a denitrifying Methanotrophic Bacterial Strain. U.S. Patent No. US 6958222 B2, 1 September 2000.

27. Stępniewska, Z.; Kuźniar, A. Cultivation and detection of endophytic aerobic methanotrophs isolated from Sphagnum species as a perspective for environmental biotechnology. AMB Express 2014, 4, 58. [CrossRef] [PubMed]

28. Stępniewska, Z.; Pytlak, A.; Kuźniar, A. Methanotrophic activity in Carboniferous coalbed rocks. Int. J. Coal Geol. 2013, 106, 1-10. [CrossRef]

29. Whittenbury, R.; Phillips, K.C.; Wilkinsom, J.F. Enrichment, isolation and some properties of methane-utilizing bacteria. J. Gen. Microbiol. 1970, 61, 205-218. [CrossRef] [PubMed]

30. Guckert, J.B.; Ringelberg, D.B.; White, D.C.; Hanson, R.S.; Bratina, B.J. Membrane fatty acids as phenotypic markers in the polyphasic taxonomy of methylotrophs within the Proteobacteria. J. Gen. Microbiol. 1991, 137, 2631-2641. [CrossRef] [PubMed]

31. National Research Council. Nutrient Requirements of Dairy Cattle, 7th ed.; National Academy Press: Washington, DC, USA, 2001; pp. 105-161, 281-314.

32. National Research Council. Nutrient Requirements of Dogs and Cats; National Academy Press: Washington, DC, USA, 2006; pp. 145-186.

33. National Research Council. Nutrient Requirements of Poultry, 9th ed.; National Academy Press: Washington, DC, USA, 1994; pp. 61-113.

34. National Research Council. Nutrient Requirements of Swine, 11th ed.; National Academy Press: Washington, DC, USA, 2012; pp. 74-104.

35. Kroneck, P.M.H.; Sosa Torres, M.E. Sustaining life on planet earth: Metalloenzymes mastering dioxygen and other chewy gases. In Metal Ions in Life Science; Sigel, A., Sigel, H., Sigel, R.K.O., Eds.; Springer International Publishing: Basel, Switzerland, 2015; Volume 15, pp. 207-224.

36. Dalton, H. Methane oxidation by methanotrophs: Physiological and mechanistic implication. In Methane and Methanol Utilizers; Murrell, J.C., Dalton, H., Eds.; Plenum Press: New York, NY, USA, 1992; pp. 85-114.

37. Aas, T.S.; Hatlen, B.; Grisdale-Helland, B.; Terjesen, B.F.; Bakke-McKellep, A.M.; Helland, S.J. Effects of diets containing a bacterial protein meal on growth and feed utilisation in rainbow trout (Oncorhynchus mykiss). Aquaculture 2006, 261, 357-368. [CrossRef]

38. Kalyuzhnaya, M.; Puri, A.W.; Lidstrom, M.E. Metabolic engineering in methanotrophic bacteria. Metab. Eng. 2015, 29, 142-152. [CrossRef] [PubMed]

39. Murrell, J.C.; McDonald, I.R.; Gilbert, B. Regulation of expression of methane monooxygenases by copper ions. Trends Microbiol. 2002, 8, 221-225. [CrossRef]

40. Hamer, G. Methanotrophy: From the environment to industry and back. Chem. Eng. J. 2010, 160, $391-397$. [CrossRef]

41. EU. Council Directive No. 82/471/EEC; EU: Brussels, Belgium, 2005.

42. Bothe, H.; Jensen, K.M.; Mergel, A.; Larsen, J.; Jřrgensen, C.; Bothe, H.; Jřrgensen, L. Heterotrophic bacteria growing in association with Methylococcus capsulatus (Bath) in a single cell protein production process. Appl. Microbiol. Biotechnol. 2002, 59, 33-39. [CrossRef]

43. Dalton, H. The Leeuwenhoek Lecture 2000. The natural and unnatural history of methane-oxidising bacteria. Philos. Trans. R. Soc. B 2005, 360, 1207-1222. [CrossRef] [PubMed]

44. Berge, M.; Baeverfjord, G.; Skrede, A.; Storebakken, T. Bacterial protein grow on natural gas as protein source in diets for Atlantic salmon, Salmo salar, in saltwater. Aquaculture 2005, 244, 233-240. [CrossRef] 
45. Woods, V.; Fearon, A. Dietary sources of unsaturated fatty acids for animals and their transfer into meat, milk and eggs: A review. Livest. Sci. 2009, 126, 1-20. [CrossRef]

46. Müller, H.; Skredea, A. Lipids from natural gas-utilising bacteria reduce plasma cholesterol concentrations in mink compared with soybean oil. In Proceedings of the International Symposium on Triglycerides, Metabolic Disorders, and Cardiovascular Disease, New York, NY, USA, 14-17 July 2005; p. 50.

47. Norferm, D.A. Lipids from Methanotrophic Bacteria for Cholesterol Reduction. Patent No. WO2005/004888 A1, 29 April 2005.

48. Øverland, M.; Skrede, A.; Matre, T. Bacterial protein grown on natural gas as feed for pigs. Acta Agric. Scand. Sect. A Anim. Sci. 2001, 51, 97-106. [CrossRef]

49. Øverland, M.; Kjos, N.P.; Skrede, A. Effect of bacterial protein meal grown on natural gas on growth performance and carcass traits of pigs. Ital. J. Anim. Sci. 2004, 3, 323-336. [CrossRef]

50. Øverland, M.; Kjos, N.P.; Olsen, E.; Skrede, A. Changes in fatty acid composition and improved sensory quality of backfat and meat of pigs fed bacterial protein meal. Meat Sci. 2005, 71, 719-729. [CrossRef] [PubMed]

51. Khmelenina, V.N.; Rozova, O.N.; But, S.Y.U.; Mustakhimow, I.I.; Reshetnikov, A.S.; Beschastnyi, A.P.; Trotsenko, A.Y.U. Biosynthesis of secondary metabolites in methanotrophs: Biochemical and genetic aspects (review). Appl. Biochem. Micro. 2015, 51, 150-158. [CrossRef]

52. Miklaszewska, M.; Waleron, M.; Waleron, K. Biotechnological potential of cyanobacteria of the genus Arthrospira. Biotechnol. 2008, 3, 119-142. (In Polish)

53. Lau, E.; Nolan, E.J.; Dillard, Z.W.; Dague, R.D.; Semple, A.L.; Wentzel, W.L. High throughout sequencing to detect differences in methanotrophic Methylococcaceae and Methylocysteaceae in surface peat, forest soil, and Sphagnum moss in Cranesville swamp preserve, West Virginia, USA. Microorganisms 2015, 3, 113-136. [CrossRef] [PubMed]

54. Knief, C. Diversity and Habitat Preferences of Cultivated and Uncultivated Aerobic Methanotrophic Bacteria Evaluated Based on pmoA as Molecular Marker. Front. Microbiol. 2015, 6, 1346. [CrossRef] [PubMed]

55. Kallistova, A.; Goel, G.; Nozhevnikova, A.N. Microbial diversity of methanogenic communities in the systems for anaerobic treatment of organic waste. Microbiology 2014, 83, 462-483. [CrossRef]

56. Pepper, I.L.; Brooks, J.P.; Sinclair, R.G.; Gurian, P.L.; Gerba, C.P. Pathogens and indicators in United Stated Class B biosolids: National and historic distributions. J. Environ. Qual. 2010, 39, 2185-2190. [CrossRef] [PubMed] 